\title{
Köszöntjük a kilencvenéves Dörnyei Sándor orvostörténészt
}

2016. május 4-én, a hagyományos Markusovszky Lajosemlékülésen Dörnyei Sándor orvostörténész Markusovszky Lajos-díjban részesült a 2015-ben publikált „A korabeli sajtó Semmelweis betegségéről és haláláról” címú, a Horus rovatban megjelent tanulmányáért. Az átadáskor nem hangzott el, így a jelenlevők közül is csak kevesen tudták, hogy a díjazott kilencvenéves!

Bizony, Dörnyei Sándor, az Országos Széchényi Könyvtárba, illetve a Semmelweis Orvostörténeti Könyvtárba még most is bejárogató orvostörténész, november 4-én tölti be 90. életévét. Malcolm Cowley, amerikai kritikus és irodalomtörténész „Nyolcvan év magasából”

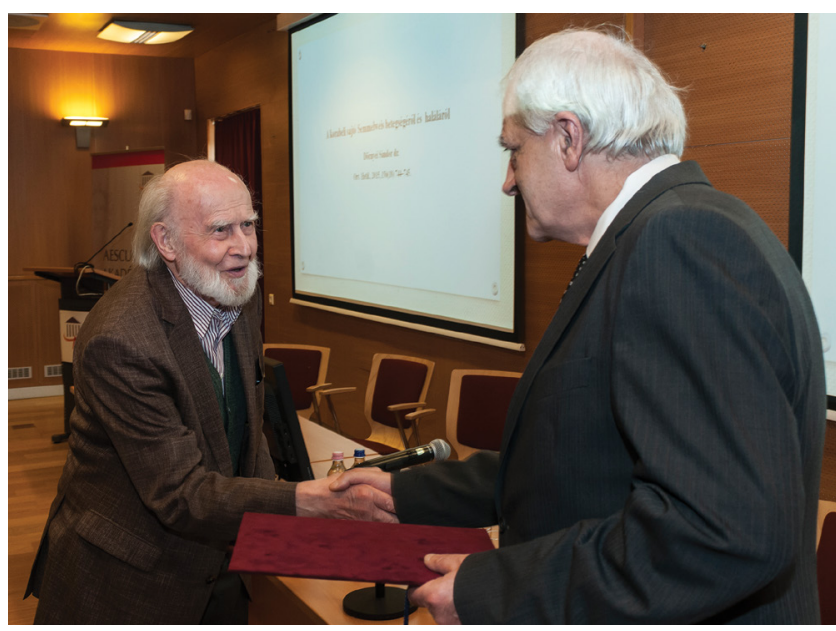

1. ábra

Prof. Dr. Rácz Károly, az Orvosi Hetilap főszerkesztője átadja Dörnyei Sándornak a Markusovszky Lajos-díjat

tekintett vissza életútjára 1978-ban, 80. születésnapja alkalmából (Európa Könyvkiadó, Budapest, 1983). Dörnyei sem a nyolcvan, sem a kilencven év magasából nem írt „,beszámolót” életéról - pedig lett volna mire visszatekintenie. E kis köszöntő ezt a célt is szolgálja.

1926. november 4-én született Szarvason. A helyi gimnáziumban érettségizett, majd Budapesten, Eötvöskollégistaként, a Pázmány Péter Tudományegyetemen 1948-ban bölcsészdoktori, majd a következő iskolaévben középiskolai tanári oklevelet szerzett. Előbb ösztöndíjasként az Országos Széchényi Könyvtárban dolgozott, majd 1950-től az Országos Könyvtári Központ alkalmazottja volt. Fiatal kora ellenére fontos feladattal bízták meg. Előbb egyedül, majd egy kis munkacsoport élén az országot járta, azzal a céllal, hogy a feloszlatott egyházi rendházak könyvtárainak értékes anyagát számba vegye és zár alá helyezze. Az értékes könyvállományból ugyanis nemcsak a fosztogatók „csipegettek”, hanem a szorult anyagi helyzetbe került egyházfók is a kódexek, ósnyomtatványok eladására kényszerültek. Dörnyeinek és kis csapatának lett a feladata az értékes kötetek központi raktárba való eljuttatása, majd leltározása. Közben, 1952 derekán, az említett központot átszervezték, munkatársai más intézményekbe kerültek. Ekkor került Dörnyei Sándor az Országos Széchényi Könyvtár gyarapítási osztályára, majd a fóigazgatói titkárságra. Emellett az 1955ben újraindított Magyar Könyvszemle szerkesztésében is részt vett. Mint annyi más kortársának szépen ívelő pályája, az övé is 1956 őszén tört meg. Mivel aktív szerepet vállalt a könyvtár forradalmi bizottságában, 1957 áprilisában persona non grata lett az állami intézményekben.

A könyvektől azonban nem tudták őt elszakítani: előbb „hónaljas” antikváriusként járta Budapest utcáit, majd a Mezőgazdasági lexikon külső bedolgozójaként kereste meg a „mindennapit”. 1958 és 1965 között az Orvostudományi Dokumentációs Központ (később Országos Orvostudományi Könyvtár) munkatársa lett. Kurrens magyar orvosi bibliográfiát és orvostudományi szakbibliográfiákat szerkesztett.

1965 októberétől nyugdíjaztatásáig, 1986-ig az Országos Gyógyszerészeti Intézet alkalmazottja. Előbb a Gyógyszerészeti és Gyógyszerterápiás Dokumentációs Szemlét szerkesztette, majd annak kettéválása után a Spectrum Pharmaceuticum és a Gyógyszerterápiás Dokumentációs Szemle szerkesztője lett. Később az Egészségügyi Világszervezet megbízásából a Drug Regulation szerkesztője.

Ez idő tájt „kóstolt bele” az orvostörténelembe is. Az Orvostörténeti Közlemények 55-56. kötete közölte a feleségével, Dapsy Henriettel közösen írt terjedelmes, háromrészes dolgozatát „Semmelweis hazai utóéletének első évtizede" címmel 1970-ben. A Semmelweis Orvostörténeti Múzeum és Könyvtár, valamint a Magyar Orvostörténelmi Társaság közös kiadványát Antall József szerkesztette.

Nyugdíjba vonulása alig hozott változást életében. Munkatársa lett az Országos Széchényi Könyvtár Régi Magyarországi Nyomtatványok Szerkesztőségének. Szabó Károly Régi Magyar Könyvtára III. kötetét öt füzettel egészítette ki, majd a XVIII. századi hazai szerzők külföldön, nem magyar nyelven megjelent közleményeinek bibliográfiáján dolgozott. 
Könyvtörténeti, bibliográfiai munkája mellett jelentős orvos- és gyógyszerésztörténeti kutatásokat is végzett. $S$ tette mindezt olyan korban, amikor még nem volt internet és egyéb, a mai kutatók munkáját megkönnyítő technikai segítség. Kézzel, illetve írógéppel papírra vetett „céduláiból” olyan alapmüvek születtek meg, mint „A magyar orvostörténeti irodalom 1715-1944”, illetve „A magyar gyógyszerészettörténeti irodalom 1944-ig”. Az előbbit a Magyar Tudománytörténeti Intézet, illetve a Magyar Orvostörténelmi Társaság adta ki 2002-ben. Az utóbbi kiadásához, 2005-ben, a Magyar Gyógyszerésztörténeti Társaság és az Ernyey József Gyógyszerésztörténeti Könyvtár is hozzájárult. Alapvető, az orvostörténészek számára nélkülözhetetlen és csak „a Szinnyei” jelentőségéhez mérhető az a három bibliográfiai kötet is, amelyeket a Borda Antikvárium segített a napvilágra: "Régi magyar orvosdoktori értekezések 1772-1849", első kötet (1998), második kötet (2001), harmadik kötet $(2010)$.

„Kilencven év magasából” visszatekintve jubilánsunk olyan kitüntetésekkel „dicsekedhetne” - de az igazi tudósra jellemző szerénysége miatt ezt sosem tette -, mint a Magyar Orvostörténelmi Társaság Weszprémi-emlékérme és -díja 2001-ben, a Magyar Gyógyszerészettörténeti Társaság Szigetváry Ferenc-emlékérme 2005-ben vagy a 2006. augusztus 20-án gazdag bibliográfusi és könyvtörténészi munkásságáért neki ítélt Széchényi Ferenc-díj. A Magyar Orvostörténelmi Társaság, amelynek alapításában részt vett és hosszú éveken át vezetőségi tagja volt, 2016. április 28-i ünnepi ülésén tiszteletbeli tagjává avatta ôt.

A 2006-ban barátai, tisztelői és tanítványai köszöntését is tartalmazó „Peregrinálók. Negyvenhárom magyarországi és erdélyi orvostanhallgató életrajza 1683-1783" címü, Dörnyei szerkesztette kötet jubilánsunk életrajzát és múveinek bibliográfiáját is tartalmazza. Mindkét tétel 2016-ban kiegészítésre szorul, hiszen Dörnyei Sándor ma is - megrokkant egészségi állapota ellenére - aktívan kutat, publikál. Ennek bizonyítéka a bevezetőnkben említett Markusovszky-díj. Kiadót keres újabb értékes kézirata: a Régi magyar orvosdoktori értekezések negyedik kötete!

Markusovszky Lajos 1861-ben vetette papírra e sorokat: „Valamint a nemzet, melynek története van, örömmel andalodik el múltján s magának abból hazaszeretetet és tetterőt merít; úgy a magyar orvos is büszkébb önérzettel tekintend jelene és jövőjére, ha a történelem tükrében látja, hogy az úttörő elődök hosszú sora vonul el előtte, s hogy a hazai orvosi irodalmat koránt sem kezdeni, hanem az elődök nyomdokain folytatni kell.” E „történelmi tükör” egyik legnagyobb, XX. századi felmutatója a kilencvenéves Dörnyei Sándor.

Az Orvosi Hetilap orvostörténeti rovata, a Horus mély tisztelettel köszönti Dörnyei Sándort 90. születésnapján.

Isten éltesse! Ad multos annos!

Csilizradvány, 2016

Kiss László dr. 